\title{
DAKWAH DALAM MEDIA SOSIAL DAN PERMASALAHAN SOSIAL DI MASA PANDEMI MEMICU BUDAYA DAN EDUKASI MASYARAKAT SAAT INI
}

Marwah Aspa.B

Institut Agama Islam Negri Parepare

Emil: marwahaspa.b@iainpare.ac.id

\begin{abstract}
Abstrak
Penelitian ini ingin mengeksplorisasi menegenai beberapa permasalahan sosial di masa pandemi memicu budaya dan edukasi masyarakat terhadap covid-19 melalui media sosial dan budaya yang ada di dalamnya. Lebih lanjut, penelitian ini turut mengidentifikasi bagaimana media mempengaruhi masyarakat dalam memberikan informasi ke masyarakat (mad'u) dan dengan melibatkan komunikasi media massa dalam strategi untuk meningkatkan kesadaran tentang usaha dengan memanfaatkan dakwah dalam pendekatan virtual etnografi yang mengacu pada pendekatan penelitian etnografi yang dilakukan dalam pengaturan online tentang internet dan media sosial. Hasil penelitian menunjukkan bahwa budaya media sosial di Indonesia dapat bertindak sebagai guru yang mampu mengedukasi dan menstimulasi masyarakat melalui media sosial dalam penelitian terbaru terkait covid-19. Sebagai pendidikan layanan kesehatan masyarakat, menyeru dan mengarahkan masyarakat ke situs web dan halaman arahan mereka untuk informasi terkait covid-19 terbaru dan terpercaya; mengajak guna untuk memasarkan layanan inovatif seperti layanan dana sosial dan perawatan kesehatan. Oleh karena itu untuk mendakwah (mengajak untuk mematuhi protocol kesehatan yang ditetapkan oleh pemerintah) di tengah pandemi seperti sekarang ini media sangat berperan penting sebagai alat dan sarana untuk menyampaikan informasi dengan frekuensi serta kapasitas yang sangat efektif di tengah pandemi guna untuk mengedukasi masyarakat.
\end{abstract}

Kata Kunci: Dakwah, Media Sosial, Permasalahan Sosial, Pandemi , Budaya, Edukasi Masyarakat 


\section{BAB 1 \\ PENDAHULUAN}

\section{A. Latar Belakang}

Persoalan penting dalam sosiologi komunikasi diterapkan dalam situasi seperti di jaman modernisasi saat ini ialah subtansi interaksi orang-orang dalam masyarakat, termasuk konten interaksi (komunikasi) yang dilakukan langsung atau yang dilakukan lewat media komunikasi, serta semua konsekuensi yang terjadi pada seluruh proses komunikasi seperti contohnya sekarang ini persoalan mengenai maratnya prekonimian di tengah pandemi menjadikan masyarakat terkungkung dalam menyikapi keadaan saat ini. Tidak hanya menyangkut persoalan medis, namun sudah menjadi persoalan yang multidimensi termasuk menyentuh bahasan komunikasi. Oleh karena itu, sebuah kekhawatiran terkait banyaknya informasi yang dibagikan membingungkan sehingga kita tidak bisa pungkiri hal tersebut memicu konflik mengenai yang ada seperti sekarang ini selain dari pada memikirkan prekonomian yang menipis, pendidikan dalam ruiang lingkup masyarakat melalui media online, juga kesehatan sangatlah ketat untuk itu, mendakwah (menyeru) kepada masyarakat hal yang sangat baik untuk melahirkan generasi milenial yang peduli terhadap situasi dan kondisi saat ini.

\section{B. Metode}

Metode penelitian ini adalah kualitatif dengan memanfaatkan pendekatan Virtual etnografi. Etnografi virtual mengacu kepada pendekatan penelitian etnografi yang dilakukan dalam pengaturan online yang dalam penelitian ini meneliti tentang internet dan media sosial. hal tersebut dilakukan atas dasar ketertarikan untuk mempelajari budaya media sosial yang sering terlibat dalam situasi pandemi covid-19 dalam budaya berbagi di Indonesia. Lebih lanjut, dengan etnografi virtual maka, penelitian ini turut mempelajari kecenderungan komunal, penyebaran informasi, dan pendidikan yang berbasis online. Batasan penelitian terletak pada cakupan media sosial yang dipilih, yaitu seperti contohnya twitter dan instagram data disajikan secara deskriktif analitis-untuk membahas tentang edukasi masyarakat terhadap covid-19 melalui media sosial dan budaya yang ada di dalamnya. Lebih lanjutnya, penelitian ini turut mengidentifikasi bagaimana media mampun mempengaruhi masyarakat dan dengan melibatkan komunikasi media massa dalam strategi untuk meningkatkan kesadaran tentang usaha penanganan dan pencegahan covid-19. 


\section{Tujuan Penelitian}

Adapun tujuan penelitian ini ialah untuk memehami sepenuhnya pengaruh media sosial pada masyarakat. Dan juga memahami Dakwah dalam Media Sosial dan Permasalahan Sosial di Masa Pandemi seperti sekarang ini, Memicu Budaya dan Edukasi Masyarakat. Mencegah gesekan konflik dalam bermedia selain dari pada itu memahami dan menaati protokol pemerintah mengenai kesehatan, agar negara kita ini menjadi negara yang makmur dan sentosa amin allahumma amin.

Internet dan budaya secara signifikan telah mendapat manfaat dari kolaborasi atas keduanya. Mengenali dampak internet terhadap masyarakat dan budaya sangat penting, dimana jelas bahwa internet dapat mempengaruhi budaya melelui kebebasan dan fleksibilitasnya. Efeknya bakhan dapat dianggap sebagai budaya sendiri. Jika dipelajari hasilnya, kolaborasi internet dan budaya di Indonesia dapat membantu. Menjadikan internet lebih bermanfaat dengan berfokus pada keakuratan informasi dengan menyadari keterbatasannya. Internet dan budaya di Indonesia memiliki konsekuensi dimana membutuhkan waktu bertahun-tahun untuk diterapkan sepenuhnya. Internet secara signifikan mempengaruhi cara orang hidup dengan berubah karena teknologinya. Misalnya individu mengubah topic dan cara komunikasi, frekuensi, dan kebiasaan mereka sebagai akibat dari keterbiasaan mereka sebagai akibat dari ketersediaan dan aksesbilitas alat komunikasi online. Perkembangan teknologi komunikasi dan efek globalisasi yang luas mengubah cara suatu masyarakat hidup, berinteraksi, belajar, dan mendefinisikan ide identitas budaya. Konsep ruang, waktu, dan jarak kehilangan makna konvesionalnya. Sayangnya, manfaat ini juga bisa dipandang sebagai kelemahannya dimana terdapat globalisasi budaya dan gerakan global dari proses budaya yang sedang berlangsung.

Penelitian yang berpendapat internet merusak budaya percaya bahwa sifat terbuka dari internet melalui media sosial memungkinkan setiap informasi untuk dijangkau oleh siapa saja dan dimana saja. Baik itu anak-anak ataupun orang dewasa yang secara instan menyalin apa yang mereka lihat atau baca dan tiru atau praktikkan sendiri tidak relevan dengan lingkungan yang mereka temukan. Di sisi lain, internet membawa budaya lebih dekat kepada lebih banyak individu, membuatnya lebih muda dan cepat diakses; yang berpotensi memupuk munculnya bentuk-bentuk ekspektasi baru untuk seni dan penyebaran pengetahuan, termasuk kaitanya dengan penyebaran informasi terkait pandemi covid-19. Penelitian ini bukan untuk mengatakan bahwa internet melalui media sosial selalu positif dan tidak ada masalah. Sebaliknya, penelitian ini mengajak pembaca untuk tidak membiarkan internet melalui media sosial membutakan masyarakat terhadap dampak negatif internet terhadap budaya. Sudut pandang yang dikonstruksi adalah individu perlu 
menyadari bahwa media sosial akan terus mengubah budaya dalam banyak hal dengan kemajuan masa depan dan peningkatan penggunaan, dan untuk penanganan awal pandemi covid-19 sehingga bisa meminimalisir dampak yang lebih besar. Untuk memahami sepenuhnya pengaruh media sosial pada masyarakat, perlu mengingat bahwa teknologi adalah budaya material. Budaya ini diproduksi dalam proses sosial dalam lingkungan kelembagaan tentu berdasarkan ide, nilai, minat, dan pengetahuan produsen mereka, baik produsen awal dan produsen berikutnya. Dalam proses ini harus mengelompokkan para pengguna teknologi, yang sesuai dan mengadaptasi teknologi daripada mengadopsinya dan dengan demikian mereka memodifikasinya dan memproduksinya dalam proses interaksi berkelanjutan antara produksi teknologi dan penggunaan sosial. Maka saat pandemik covid-19 ini masyarakat harus menempatkannya dalam konteks transformasi struktur sosial secara keseluruhan, serta dalam hubungan dengan karakteristik budaya dari struktur sosial, dimana budaya media sossiL telah menjadi keniscayaan di masyarakat Indonesia.

Interfrensi internet dan informatika perilaku memiliki potensi untuk membantu individu baik pasien susoect covid-19 dan masyarakat umum dalam memodifikasi perilaku untuk meningkatkan kesehatan fisik, mental, dan perilaku. Secara khusus,interfensi media sosial memiliki beberapa keuntungan, termasuk aksebilitas yang luas melintasi hambatan geografis yang bisa menjangkau batasan spasial dan efesiensi biaya. Saat ini, pertumbuhan situ jejaring sosial membawa peluang baru untuk menyebarluaskan interfrensi kesehatan masyarakat dan mempromosikan peningkatan besar di bidang perilaku kesehatan.

Peningkatan dalam cara berkomunikasi dan berinteraksi dengan telah memengaruhi bagaimana generasi net dididik. Orang tua dengan generasi baby boomer hingga (mungkin) generasi $\mathrm{X}$ diajar dengan gaya yang cenderung kaku. Ada jawaban yang benar dan jawaban yang salah untuk semuanya, namun dalam sistem pendidikan saat ini, generasi $X$, atau generasi Net didorong untuk menjelajahi dunia dengan cara mereka sendiri. Penyebaran informasi terkait covid-19 dengan menggunakan sistem seperti online melalui media sosial telah berinfestasi dalam membangun ruang lingkup mereka sendiri, dimana mereka dapat menjadikan diri mereka agen pendidikan dan agen kesehatan. Pengguna dapat secara langsung dapat menginformasikan masyarakat luas tentang hal-hal terkait masyarakat luas tentang hal-hal terkait covid-19 pada platform media sosial secara interaktif.

Perubahan dalam masyarakat sebagian besar disebabkan oleh bagaimna informasi ditransmisikan, dengan orang-orang yang selalu terhubung dan terusmenerus mendapat informasi tentang apa yang terjadi dalam kehidupan seseorang atau apa yang terjadi di seluruh dunia. Selain sistem tradisional yang mengandalkan diagnosa yang dilaporkan dari laboratorium, media sosial 
semakin diakui sebagai sumber terkait informasi dan peringatan kesehatan masyarakat. Selain itu, komunikasi mendukung koordinasi sumber daya termasuk peralatan kesehatan, pengelolaan kesehatan, personel kesehatan, dan informasi selama situasi krisis pandemic Covid-19. Covid-19 merupakan penyebab utama moralitas dan morbiditas di seluruh dunia saat ini, yang sebagian besar dipromosikan oleh perilaku gaya hidup yang tidak sehat dan tidak disiplin dalam social distancing dan physical distancing. Memang, pola makan yang buruk merokok, dan penyalahgunaan alkohol adalah faktor risiko umum untuk penyakit pernafasan dan koondisi kronis lainnya, yang memperburuk dampak Covid-19, namun usaha-usaha yang telah disarankan oleh pemerintah pada dasarnya memiliki urgensi yang tinggi.

Di dalam penyebaran informasi terkait Covid-19, media sosial atau bentuk teknologi lainnya dari bentuk pendidikan, yang sebagai institusi sosial perkembangannya turut dipengaruhi oleh pertumbuhan media yang cepat. Media selalu menjadi lembaga sosial. Banyak persepsi dan norma dalam masyarakat didasarkan pada informasi yang mereka terimaterlebih dari informasi terkait Covid-19. Sebelum mengarah pada media social, media cetak dapat dijadikan sebagai sebuah contoh. Di dalam sudut pandang politik kekuasaan, di mana pada saat tidak ada surat kabar, para penjajah masih dapat mempertahankan kontrol atas orang-orang dengan menetapkan diri mereka sebagai pihak yang lebih baik dan unggul. Jadi jelas, berdasarkan ini kita dapat melihat bahwa media selalu menjadi lembaga sosial. Ketika teknologi mulai tumbuh ke dalam setiap aspek kehidupan manusia, maka media adalah sumber utama informasi dan kebutuhan yang terus meningkat untuk kehidupan.

Munculnya teknologi adalah karena perubahan yang terjadi dalam kehidupan manusia. Secara khusus, dengan kostribusi pada teknologi adalah karena perubahan yang terjadi dalam kehidupan manusia. Secara khusus, dengan konstribusi pada teknologi informasi dan komunikasi, sektor pendidikan telah mendapatkan banyak manfaat. Di dalam media twitter dan instagram, bahkan mereka telah membantu dalam mengarahkan masyarakat ketika mengetik kata kunci "covid-19" dalam kolom pencarian.

Sistem algoritma dalam instagram langsung memberikan tawaran kepada penggunanya untuk menuju tautan resmi tentang covid-19. Selain itu, tagar instagram juga membantu dalam pencarian informasi terkait covid-19 dengan kata kunci \#covid-19. Media sosial dapat menjadi saluran informasi pelengkap ke sarana resmi untuk pengumpulan data kesehatan ketika pandemi covid-19 ini, yang sebelumnya telah dianggap sukses seperti kegiatan pengawasan epidemologis dan kontrol yang dilakukan oleh otoritas kesehatan. Untuk alasan ini, semakian banyak organisasi, professional, dan lembaga ilmiah melihat kebutuhan untuk memanfaatkan sumber daya informasi kesehatan berdasarkan platform media sosial. 
Hal serupa terjadi di twitter, di mana mereka memberikan tautan cepat menuju situs resmi covid-19 yang dikelola oleh pemerintah di halaman utama mereka. Kemudahan akses informasi tersebut tentunya dapat dimanfaatkan oleh masyarakat dalam mengedukasi terkait covid-19.

Adapun pertanyaanya tentang hubungan media dengan identitas budaya nasional, ada jawaban yang mudah dan jelas: media harus menjadi penting karena mereka begitu lazim. Oleh karenanya, media sosial tidak hanya menawarkan berjuta informasi yang ada di dalamnya, namun menuntut kedewasaan dan kematangan berpikir penggunanya. Dengan dampak kuat dari media dalam membentuk proses sosialisasi dan perilaku orang-orang, dapat dikatakan bahwa media adalah kekuatan yang kuat dalam membentuk identitas nasional dalam pandemi Covid-19 ini. Untuk institusi demokratis, media memainkan instrument yang kuat dalam membentuk opini publik baik dalam bidang politik, budaya dan ekonomi yang dikaitkan dengan kesehatan dalam covid-19 ini. Kehadirannya media sosial yang begitu erat dengan masyarakat menyebabkan warga di negara-negara demokratis menganggapnya sebagian dari kehidupan.

Seperti yang pribadi lihat saat ini, masyarakat juga menggunakan media sosial untuk berbagi pendapat, mencari informasi, dan berbagi cerita tentang pengalaman mereka. Lebih lanjut, penelitian menunjukkan bahwa $60 \%$ dokter melihat media sosial sebagai jalan untuk memberikan layanan kesehatan yang lebih baik kepada pasien. Bagi pasien, media sosial adalah tempat untuk mendapatkan saran dari rekan-rekan yang mungkin mengalami masalah kesehatan yang sama. Mereka juga mencari saran untuk membuat perubahan gaya hidup dan solusi untuk masalah kesehatan yang mungkin mereka alami. Misalnya, seseorang yang peduli tentang pencegahan covid-19 melalui gerakan cuci tangan menggunakan sabun, mereka dapat mencari blog, atau meminta saran dari anggota komunitas media sosial. Mereka berusaha untuk meredahkan kekhawatian tentang covid dengan mengakses atau membuat kontek media sosial tentang efektivitas gerakan cuci tangan menggunakan sabun guna untuk membunuh virus covid-19.

\section{BAB II PEMBAHASAN}

\section{Media sebagai sarana komunikasi}

Media menjadi sistem komunikasi manusia kian penting dalam kehidupan. Komunikasi yang dilakukan oleh manusia seperti komunikasi intrapribadi, antarpribadi, kelompok antar budaya dan komunikasi massa. Oleh karena itu dalam peranan ini, komunikasi massa merupakan jaringan yang 
menghubungkan banyak penerima kepada satu sumber, sementara teknologi media baru biasanya menyediakan berbagai macam hubungan interaktif (McQuail, 2011:18). Media massa memiliki peran strategis, sebagai saluran yang menyampaikan informasi kepada publik atau khalayak. Komunikasi massa juga mempengaruhi konteks sosial dan sosial mempengarui media. Dengan kata lain, terjadi hubungan transaksional antara media dan masyarakat. Seiring dengan perkembangan jaman, media massa terbagi menjadi beberapa jenis, yaitu media cetak seperti surat kabar, majalah, tabloid, bulletin, jurnal, dan yang lainnya. Media elektronik seperti televisi, radio, telepon, handphone, pager, dan sampai sekarang mampu memunculkan media baru (New media) yaitu internet. Sehingga di dalam perkembanganya perusahaan-perusahaan media saling bersaing untuk mendapatkan hati para pembacanya.

Dakam kehidupannya, manusia harus berkomunikasi dengan manusia lainnya untuk mempertahankan hidup. Mendapatkan informasi dari orang lain dan memberikan informasi kepada orang lain. Manusia perlu mengetahui apa yang terjadi di sekitarnya, dikotanya, di negaranya dan semakin lama semakin ingin tahu apa yang terjadi di dunia. Sehingga dalam hal ini, tugas dan tujuan per atau media massa adalah untuk mewujudkan keinginan melalui media baik dari media cetak maupun media elektronik seperti radio, televise, maupun internet (Kusumaningrat, kusumaningrat,2006:27) ${ }^{1}$

Ada salah satu kasus yang terjadi pada masa pandemi saat adalah adanya budaya yang sebelumnya tak pernah dipikirkan selama ini. Terkadang cadar diremehkan seolah-olah itu adalah musuh atau teroris namun ketika hadirnya wabah seperti ini justru para alat yang dipakai oleh wanita kini menjadi pelindung dari virus ini, seorang desainer yang kebanyakan membuat baju yang menarik,dan bentuk yang luas biasa kini menjadi pakaian yang menutupi mulai dari muka sampaik kebawa mata kaki.semua ini adalah perubahan buday. dengan hadirnya wabah ini mampu memberikan efek terhadap masyarakat mampu berkontribusi dengan pemerintah lewat pakaian yang mereka bentuk yang agak sesuai dengan protokol kesehatan

Kemudian kaitanya dengan dakwah,tentu dakwah juga harus berperan penting dengan situasi ini karena banyak masyarakat takut denga keadaan ini,pendakwah tidak lagi berjalan kesana kemari dari rumah-kerumah untuk mengajak tetapi mereka dakwah mereka barengi dengan situasi apakah itu edukasi yan baik dan menyampaikan kita tak perlu takut dengan hal ini,kita Cuma berdiam dirumah,hidup bersih dan terus berdoa kepada tuhan. Media sosial juga dapat digunakan sebagai alat penelitian dan tracking dalam kesehatan masyarakat terkait covid-19. Misalnya para peneliti telah

${ }^{1}$ https://www.researchgate.net/publication/.340631248_Budaya_Media_Sosial_ Edukasi_Masyarakat_dan_Pandemi_COVID-19. 
menggunakan media sosial untuk melacak dan memperkirakan penyebaran wabah covid-19. Dengan begitu banyak informasi yang tersedia secara publik tentang berbagai penyakit dan masalah kesehatan masyarakat lainnya, ada potensi besar untuk menggunakan media sosial sebagai sumber penambangan data untuk pengembangan penanganan pandemi. Media sosial bahkan dapat digunakan untuk melacak opini publik misalnya terkait penggunaan desinfektan dan upaya-upaya lain untuk pencegahan serta penanganan covid-19. Lebih lanjut lembaga kesehatan dan professional dapat bertindak berdasarkan informasi yang beredar di media sosial. Misalnya, jika mereka mengetahui wabah penyakit yang akan datang, mereka dapat merencanakan ketersediaan dan penyedia layanan. Mereka juga dapat mengarahkan penelitian yang tepat untuk menangkal dampak atas informasi medis yang salah. Hal tersebut dikarenakan sifat global yang dimiliki oleh media sosial, dimana aplikasi informasi media sosial dapat digunakan di seluruh dunia.

Usaha dari media sosial yang mengarahkan langsung berita-berita terkait Covid-19 yang saat ini merupakan tingkat urgensi paling tinggi, merupakan bentuk pencegahan terhadap mereknya hoax yang dapat berpotensi meresahkan masyarakat Indonesia dan berpotensi menurunkan rantai kenasionalismean masyarakat. Sumber identitas masyarakat yang paliang kuat adalah budaya politik komunal dari domain publik. Budaya adalah istilah yang sering merujuk pada cara hidup, dengan agama, bahasa resmi, juga memiliki tradisi dan gaya artistik sendiri serta berbagai macam kebiasaan dan pengaturan keluarga yang membedakan dari masyarakat yang lain. Hal ini berpengaruh juga tidak lepasnya dari peran surat kabar, radio, dan televisi untuk mendorong masyarakat untuk melihat fenomena nasional secara umum, dan berfikir secara patriotik tentang negara mereka mereka sendiri pada khususnya. Akan tetapi, hubungan antara media massa dan negara ini tidak memiliki teori dan secara empiris belum teruji. ${ }^{2}$

${ }^{2}$ Alber, Julia M. Samantha Paige, Michael stellesfson, andjay M.Bernhardt. Social media selfeffi cacyo fheal theducations pecialists.health promotion practice 17, no6 (2016) : 915-921. 


\section{KESIMPULAN}

Oleh karena itu dalam kondisi di tengah-tengah memanasnya informasi mengenai covid-19. Meskipun banyak faktor yang mempengaruhi perilaku yang berhubungan dengan kesehatan, kesadaran akan resiko untuk membuat perubahan perilaku masyarakat adalah unsur utama untuk meningkatkan kesehatan individu dan status kesehatan masyarakat agar terhindar dari covid19. Komunikasi media massa dalam hal ini adalah media sosial, merupakan komponen mendasar dari banyak strategi promosi kesehatan yang dirancang untuk mengubah perilaku risiko kesehatan. Media sosial memiliki kapasitas untuk menjangkau dan mempengaruhi jutaan orang Indonesia secara bersamaan. Kekuatan media yang paling jelas terletak pada jumlah individu yang dapat mereka jangkau. Media sosial dapat mempengaruhi perilaku individu sehingga diperlukan untuk mempertahankan kebiasaan atas perubahan perilaku untuk sadar kesehatan. Selain itu, ketika pola pemberian layanan kesehatan terus berubah, media dapat memberikan informasi berharga kepada masyarakat tentang opsi dan sudut pandang lain. Media sosiak mengirimkan informasi kesehatan dengan kesengajaan atas kuasa dari pemilik akun. Sebagian besar media sosial mendapatkan sumber informasi melalui berita dan fitur-fitur lainya secara tidak langsung masuk kedalam rana popular dalam situs hiburan massa. Berita atau liputan lain dari informasi kesehatan dan perkembangan medis dapat menyelamatkan nyawa yang juga tak terhindarkan bagi mayoritas orang Indonesia.

Media sosial telah menjadi salah satu media untuk edukasi, dimulai dari banyaknya informasi dan peluang terjadinya interaksi serta arahan untuk menuju pengembangan informasi ke dalam tautan lain. Hal tersebut menandakan bahwa selain keterkaitanya sebagai media hiburan, media sosial dapat dijadikan sebagai alternative sumber jawaban untuk pertanyaan keseharian, termasuk informasi dan pertanyaan terkait covid-19.

Tulisan ini ingin mengeksplorasi tentang edukasi masyarakat terhadap covid-19 melalui media sosial dan budaya yang ada di dalamnya. Lebih lanjut, penelitian ini turut mengidentifikasi bagaimna media mempengaruhi masyarakat dan dengan melibatkan komunikasi media massa dan strategi untuk meningkatkan kesadaran tentang usaha penanganan dan pencegahan covid-19. 


\section{DAFTAR PUSTAKA}

Artikel mengenai Dakwah, budaya media sosial, Edukasi masyarakat, dan Pandemi covid-19.

https://www.researchgate.net/publication/.340631248 Budava Media Sosial E dukasi Masyarakat dan Pandemi COVID-19.

Alber,JuliaM.SamanthaPaige,Michaelstellesfson, andjayM.Bernhardt.Social mediaselfefficacyofhealtheducationspecialists.healthpromotionpractice17,no6 (2016):915-921. 